\title{
Principles and Practices of L1/L2 Use in the Japanese University EFL Classroom
}

\section{Keith Ford \\ Waseda University}

This article considers the issue of classroom language policy in the context of an EFL environment. Specifically, it focuses on the context of university settings in Japan. Using a semi-structured format, I interviewed 10 university teachers about their principles and practices concerning both teachers' and students' L1 use. Policies ranged from those requiring strict L2 only classrooms to those allowing students to use the L1 whenever they needed. The policies of most teachers were not constrained by any institutional requirements or particularly influenced by critical pedagogy or any language learning theory. Rather, they tended to be determined by pragmatism, individual beliefs, and personality.

この論文では、EFL環境というコンテクストにおける教室内での言語使用の方針について考 察する。とりわけ、日本の大学環境というコンテクストに焦点を置く。半構造的インタビューを用 いて、教員と学生の第一言語の使用について10人の大学教員に彼らの理念と実践について尋 ねた。彼らの言語使用の方針は、第二言語のみの教室を厳密に求めるものから、学生の第一言 語の使用を必要である時には認めるものまで、多岐に渡っていた。ほとんどの教員の方針は大 学側の要求により強制されたものでも、とりわけ批判的教育学や言語学習理論により影響され たものでもなかった。むしろ、実用的理由、個人的信念、性格により決定される傾向にあった。

Keywords: L1 use, teacher beliefs, classroom practice

7 he last few decades have seen a growing interest in critical pedagogy in both ESL and EFL contexts. Founded on critical social and educa-

1 tional theory (e.g., Freire, 1972a; Habermas, 1972), critical pedagogy is an approach to language education which places sociopolitical considerations high on the classroom agenda. It incorporates a set of principles

JALT Journal, Vol. 31, No. 1, May, 2009 
and practices that aim "not only to change the nature of schooling, but also the wider society" (Pennycook, 1990, p. 24). However, while taking a radical critical stance implies emancipatory and transformative action (Freire, 1972a, 1972b; Giroux, 1988), a more practical approach-particularly in an EFL context like Japan-is reflected in calling curriculum and classroom practices into question. In following this tendency, and with particular reference to my own teaching context of tertiary education in Japan, this article addresses the commonly accepted practice of teachers imposing an "English-only" directive on the EFL classroom.

Throughout 10 years of university teaching experience in Japan, I have tended to favor a strict English-only classroom policy, in terms of both teacher and student language use. However, this is something I am beginning to question, from both critical and practical perspectives. Various critical proponents, in presenting their views on linguistic imperialism (Phillipson, 1992), the notion of voice (Pennycook, 1994) and participatory pedagogy and education (Auerbach, 2000), have encouraged a positive reevaluation of L1 use. This has led me to consider to what extent in the EFL context of Japanese universities teachers are making a conscious decision to make use of the L1.

There is also a more pragmatic consideration in making a degree of L1 use a logical alternative to English only: the increasingly low-level English comprehension skills of many 1st-year Japanese university students. In response to rapidly declining numbers of university-age Japanese following decades of falling birth rates, many universities may find themselves adopting a more open policy to student intake by lowering entrance standards. This is reflected in the English ability of incoming students, which at times can create something of a classroom dilemma as many have real difficulty in understanding the most basic native-speaker speech.

In addition to critical and practical considerations, there is a body of research suggesting that L1 use can assist L2 learning at various proficiency levels, such as providing a sense of security to learners and reducing affective barriers (see Auerbach, 1993). Moreover, in terms of theoretical support, Vygotskian sociocultural theory (see Lantolf, 2000), with its concepts of scaffolding, semiotic mediation, and the Zone of Proximal Development, provides an analytical framework supporting student L1 classroom use.

However, despite the support of influential theory and research findings favoring L1 use, much of the anecdotal EFL-teaching literature suggests that English only, as a guiding principle of communicative methodologies, remains a dominant practice among native-speaker teachers. I therefore wished to get a clearer picture of L1/L2 classroom language policies of 
native-speaker EFL teachers at Japanese universities, as well as ascertain whether their principles and practices reflect a critical or more practical perspective on language pedagogy.

\section{The L1/L2 Only Debate: A Review}

Since the publication of Phillipson's (1992) Linguistic Imperialism there has been a radical change in views regarding the issue of the use of L1 in the L2 classroom. Phillipson's work has been particularly influential in critiquing various tenets of the dominant ELT paradigm, such as English being best taught monolingually and by native speakers. This "monolingual fallacy," Phillipson argues (pp. 185-193), is rooted in the maintenance of colonial power and in misguided and negative beliefs about bilingualism. In terms of classroom practices, the imposition of an English-only approach can therefore be considered as authoritarian and reflecting a supposition of linguistic and cultural superiority. On the other hand, students' freedom to use their L1 represents a liberation and democratization of the L2 classroom.

In an ESL context, proponents of critical pedagogy have argued that learners' freedom to use their L1 in the second-language classroom is nothing less than an expression of "linguistic human rights" (e.g., Skutnabb-Kangas, 1999). In such a context, English-only policy is seen as being representative of an ideology maintaining social injustice and existing unequal power relations (e.g., Auerbach, 1993; Corson, 1999). Indeed, Auerbach critiques the tradition of emphasizing communicative competence as a primary language goal, suggesting that the resulting practice of "survival English in an English-only classroom" (p. 13) restricts ESL students' participation in society and avoids classroom communication about the real concerns affecting their lives.

In an EFL context, Cook (2001) points out how a dominant English-only agenda has led to the use of such pejorative language as avoid, ban, and confess to consistently describe any L1 use. As a result, for many EFL teachers L1 use is rarely openly discussed, Prodromou (2002, p. 6) observing how it has become something of a "skeleton in the cupboard," a guilty secret. Indeed, some teachers may feel that openly resorting to L1 use represents a contradiction to their traditional direct-method training.

There are, however, strong pedagogical arguments for using L1 in the FL classroom. For example, as Weschler (1997) observes, given the actual time needed to develop any real degree of fluency, limited class time could be better spent on using the L1 as a means of teaching L2 communication skills and strategies. The efficiency argument is further supported by Cook (2001), who suggests L1 use by teachers is more appropriate for task clari- 
fication and can lead to more effective learning. Furthermore, in terms of authenticity, Clanfield and Foord (2003) support the appropriate use of L1 in a range of activities, from conversation starters to practicing code switching skills, suggesting that this "reflects the natural interplay of L1 and L2 which is inherent in second language acquisition" (cited online).

Despite strong social, political, and indeed practical arguments for L1 use, caution is needed in simply applying principles of ESL critical pedagogy to EFL classroom contexts. For example, the motivation of an ESL learner who needs English to function in society on a day-to-day basis is likely to be very different to the motivation of an EFL student who is obliged to take an English credit regardless of interest or study major, as is the case at most Japanese universities. Also, it is often pointed out (e.g., Polio, 1994) that in SL settings learners have various opportunities outside of the classroom to develop language proficiency, but in typical FL environments the amount of input is highly limited, with classroom time being learners' only opportunity to actually use their L2 for developing speaking fluency. This is a particular concern in the context of Japanese university English education, where most students have already spent 6 years at high school studying English with the purpose of passing written examinations but have little to no ability to actually use the language in any communicative sense.

One way to approach the L1/L2 only debate from a learner-centered perspective is to find out what students themselves want in terms of L1 and L2 use. For example, in surveying 300 EFL students with Greek as L1, Prodromou (2002) found that while many agreed that the teacher should know and use the L1, paradoxically most "feel they should be hearing and using English" (p. 7), including for procedural uses. Despite encouraging teachers to take a sympathetic view of learners' language and culture, Prodromou concludes from his findings that teachers should not "waste any opportunity to provide students with natural, comprehensible input. Procedural language in the classroom is too good an opportunity for natural English to waste on the mother tongue" (p. 7).

Various university instructors in Japan have also offered results from closed-format student questionnaires to validate the use of Japanese (e.g., Burden, 2000; Critchley, 1999; Cullen \& Morris, 2001). Critchley surveyed 160 university students and found that $91 \%$ expressed "a preference for some degree of bilingual support in English classes" (p. 13), concluding that "the English-only paradigm may not be entirely appropriate for Japanese contexts" (p.3). However, such comments and findings often serve to reignite the L1/L2 only debate. For example, in responding to Cullen and Morris, while McAulay (2002, p. 20) calls for foreign instructors to be "displaying 
bilingual competence in the classroom, on campus and in the community at large," Ryan (2002, p. 20) cautions against use of the L1, emphasizing that we "maximize the opportunities for students to engage meaningfully in the L2."

But whatever stance is taken regarding this issue, encouraging the use of English in class can be done in a sensitive and rational way. It need not be dictated in an authoritarian manner as in the following anecdotal scenario from Weschler (1997, cited online): "Class. We are here to learn English. As of today, you are not to use any Japanese in this room. This is an 'English-only' class." Such enforcement of an English-only policy may even extend to such extremes as fining students for talking in the L1 and demanding they use only monolingual dictionaries. Critical pedagogues would argue that these measures reflect an agenda of establishing unquestioned control over learners, and directly conflict with their freedom of choice and individual learning preferences. While taking such a dictatorial attitude to classroom language use may be governed by institutional requirements, or by genuine pedagogical principle, it may also result from a teacher's lack of proficiency in the students' L1.

This leads us to consider the key issue of the L1 (i.e., Japanese) knowledge/ ability of native-speaker English teachers. Clearly, in a multilingual classroom setting the instructor cannot be expected to know the various languages of the students, and any use of a student's L1 by the teacher may be seen as exclusionary. However, in a monolingual setting like Japan the L1 can be used effectively. Indeed, the main forum for publications by practicing teachers in Japan, The Language Teacher, has published various articles addressing the issue of teachers needing a working knowledge of Japanese, including: the call for native-speaker teachers of English to make the effort to learn the L1 to empathize with learners (Barker, 2003); the need for preparing practical and instructional L1 phrase lists (Cole, 1998); the development of sufficient L1 knowledge to make contrastive study part of the language classroom (Yamamoto-Wilson, 1997); and the highlighting of communicative ability in Japanese as being increasingly required for jobs (Glick, 2002).

Given these strong arguments for teachers developing L1 ability for classroom use, it is important to consider a rational and principled approach. Without establishing a set of clear guidelines as to how and when L1 is used it may be difficult for a teacher to monitor not only their students' use but also their own. This has resulted in calls for: the deliberate and systematic use of L1 (Cook, 2001); having "the pedagogical framework" in place to support L1 use (Prodromou, 2002, p. 6); finding a balance that suits one's teaching philosophy (Bawcom, 2002); teachers to be "explicit with regard to activity, purpose, 
mode and group configuration" (Polio, 1994, p. 153); and the selective use of L1 "based on critical analysis of their own contexts" (Auerbach, 1994, p. 158).

Despite there being a growing tendency toward recognizing not whether to use L1 but when to use it, the L1/L2 only issue remains hotly debated. For some, freedom to use the L1 is an ideological issue based on assumptions about existing power relations, while for others a strong commitment to L2 use is based on pragmatism and sound SLA theory that underlines the importance of negotiation for meaning and maximizing $\mathrm{L} 2$ input. With this debate in mind, I interviewed 10 teachers concerning their policy toward L1/L2 use.

\section{Method}

\section{Participants}

The participants in this research were 10 native-speaker EFL teachers, all qualified at least to Master's or Diploma level in TESOL/TEFL or Applied Linguistics. Working at various universities throughout the Tokyo region of Japan, they teach a range of skills and content classes, to both English majors and nonmajors. Their average classes are of about 20-30 students, giving them a clear rationale for using a lot of pair and group work, an important consideration given that I was interested in both teachers' and students' language use. Half of the teachers were female and half male, aged between 30 and 60, and all had spent between 8 and 17 years teaching either at Japanese universities and/or high schools. At the time this research was conducted, they were all colleagues of mine. Five were British, two Australian, two American, and one Irish. Seven of the teachers were part time, working at a number of universities. The other three were full time, either with limited-term contracts or tenured positions. To a certain extent the participants represented a purposive sample (Cohen, Manion \& Morrison, 2000, pp. 102-104) in that through my knowledge of these instructors I felt they probably represented a range of levels of Japanese language ability and of views and practices regarding L1 use.

\section{Research Questions}

The particular research questions that I set out to address were:

1. What stance do native-speaker EFL university teachers in Japan take on the issue of L1 use in the L2 classroom, and how do they rationalize it?

2. Do they set specific guidelines for themselves regarding L1/L2 use?

3. Is their policy negotiated in any way or constrained by institutional demands? 
4. Do any of them have a critical perspective to support or question their policy?

\section{Data Collection}

As I had specific research questions that I wished to address and that I planned to use as the basis of the discussion section of this paper, I opted for a semistructured rather than open-ended style of interview. This allowed participants to control topic and introduce various related issues regarding L1/L2 use while still addressing a set of prepared questions that would form the main structure of the interview. Mills (2001, p. 285) describes this kind of interview as one that "combines features of a pre-planned determined framework with scope for the interviewees to talk at length, go off at a slight tangent, pursue a theme."

With two colleagues, I piloted a set of interview questions, changing a number of them, and as a result selecting 14 questions (see Appendix) which acted as a structured framework for further interviews. Though I found that to a certain extent interviewees tended to naturally touch upon questions at various stages in the interview, I did find myself getting them to restate or clarify at the planned point in the interview. I made this a deliberate policy during all other interviews, primarily as a way of facilitating the process of analysis, cross-referencing, and comparison of participants' responses.

\section{Interview Procedure}

The interviews took place either at my own home or at locations convenient to the interviewee. Prior to the interview we spent an hour or so chatting over lunch, provided or paid for by the researcher as a means of thanking the participants. Knowing all of the interviewees quite well as teaching colleagues was, I felt, an important contributing factor in creating a relaxed atmosphere for a face-to-face interview.

Before beginning each interview, I stated that I was concerned primarily with classes they taught that had a major oral component, rather than pure composition or reading skills classes. I asked permission to record them using a small unobtrusive portable tape recorder, explaining that only I would be listening to the tapes and that they would be erased once the piece of research was completed. I also clarified the research purpose, for while I had indicated to them prior to the interview that the topic was related to principles and practices of teaching, I had not indicated that the specific topic was L1/L2 use. The main reason for this was that I wanted to ensure a degree of spontaneity and natural flow in talking about their views and experiences. 
I was very fortunate that all of the participants seemed to be comfortable in talking about the topic and that they were able to do so with little prompting, encouragement to expand, hesitation, or awkwardness. The fact that they were all keen professionals, and enjoyed their work and talking about it, was undoubtedly helpful. Most interviews lasted 30-40 minutes, with the range being from 25-51 minutes.

\section{Data Analysis}

As I listened to each recorded interview, I made summary notes, as well as paraphrasing and transcribing particularly significant comments. This amounted to $41 \mathrm{~B} 5$ pages, 3-5 pages for each interview. As I planned to use the research questions as a basis for discussion categories, and in order to assist cross-referencing of topics, I then made marginal notes for each interview using the following lettering system: policy and rationale for teachers' language use (PR-T); policy and rationale for students' language use (PR-S). I also coded comments that suggested a critical perspective (CP); negotiation of policy (NP); and institutionalized policy (IP). Following this analysis I was able to cross-reference and bring together common strands of the 10 interviews for the purpose of presenting results and discussion. In the following discussion, I have used a simple anonymous coding method of P1-P10 to distinguish comments made by the 10 participants (following Cox \& Assis-Peterson, 1999).

\section{Results and Discussion}

\section{Rationale for Teachers' Use of English Only}

In terms of teachers' language use, the majority of participants supported an English-only approach. One strong pedagogical argument for this was that if learners know that the teacher will use the L1, then they stop concentrating so much on processing information in L2, knowing they will get an explanation or instruction clarified in Japanese. Also, as one teacher put it, if students understand that their teacher's Japanese is good, they will use it as a "crutch" (P7) and address the teacher in L1. Knowing they can be more easily understood in Japanese can therefore limit their own opportunities for L2 practice and for developing the ability to negotiate meaning in the L2. One teacher observed that "Once you start speaking in Japanese at all then they don't work so hard, they don't listen as hard, they start thinking more in Japanese" (P5). Furthermore, for those teachers who try to encourage student L2-only use, it was considered that any teacher use of Japanese can act like a knock-on effect: "I would imagine if the teacher is using Japanese, it is giving the go ahead for the students to use Japanese" (P6). 
Another rationale for taking a strong line in using only English focused on the issue of teachers recognizing their responsibility to provide students with plenty of rich comprehensible input. A teacher who described himself as "a 100 per cent English-only proponent" (P1) emphasized the need for maximizing students' time spent hearing the L2 as they had so little opportunity to do so otherwise in a typical FL setting ("To be exposed to as much English as possible in a limited time"). He stressed the importance of developing an effective teacher talk style, as opposed to opting to use Japanese for explanation or instructions. It was also pointed out that some teachers may consciously or unconsciously be using classes as an opportunity to practice their own Japanese rather than trying, and possibly struggling, to be understood in English.

One teacher, who was part of a coordinated program with an institutionalized English-only policy, underlined the importance of in-house training and orientation of teachers, as well as students. He suggested this is especially important regarding process language, instruction, and task directions, when the teacher should give "simple instructions, then model" (P2). Furthermore, to facilitate students' L2 understanding they can be easily and effectively trained in various listening strategies and in comprehending instructional, formulaic expressions. This was supported by other teachers who highlighted essential techniques and strategies employed to effectively manage their L2-only policy, such as the careful use of teacher talk, modeling, reiteration, conscious recycling of key phrases and vocabulary, effective use of handouts and board, as well as the need for patience as opposed to using the L1 when students do not understand something the first time.

\section{Rationale for Teachers' Use of $L 1$}

While the majority stated that they tried to use English as much as possible, various teachers highlighted the occasional conscious use of L1 for humor and effect, with the purpose of creating a positive, friendly classroom atmosphere conducive to learning. For example, this involved using phrases like "Eigo dake please" ("English only please") and "Wakatta" ("Do you understand?"), as one teacher remarked, simply "to get a laugh" (P1). Another teacher observed, "I use Japanese riddled with mistakes and students just laugh" (P9), the point being not only to create a relaxed and friendly atmosphere but also to communicate the idea that students should not be worried about making mistakes when using the L2.

The occasional use of Japanese by those considering themselves essentially English-only users was also rationalized as an expression of empathy ("I'm trying to learn a bit of your language also" (P3), as a convenient and 
simple way of clarifying any confusion regarding instructions or tasks, and as a "time-saving device" (P3), for example using it for short directions as in "Issho ni yomimasho" ("Let's read together"), despite these being-as one strict English-only proponent pointed out-formulaic and easily learnt phrases given practice and patience.

There was, however, one teacher among the interviewees who stood out as taking a particularly proactive stance toward L1 use. He pointed out the initial important goal of students feeling as relaxed as possible in the classroom and of avoiding any possible tension or confusion as a result of not understanding native-speaker English. He considered that teacher use of the L1 was one way of showing support for students dealing with required English courses that they would otherwise find a real struggle: "If you need to speak Japanese to a student to help them get through then that is fine" (P9). The use of "get through" here may reflect how students are seeing English classes primarily as a chore and an obligation rather than as any useful opportunity to develop a skill for their future. Indeed, given that most 1st-year university English classes in Japan are not optional, there is credence in the view that we should assist students in "getting through" these obligatory credits with the minimum amount of stress and discomfort.

\section{Rationale for Students' Use of English Only}

The question of if and when students should use the L1 in class appeared to be a more divisive issue than teachers' use. A few teachers expressed a near zero tolerance to L1 use among students, one suggesting that "If your target is a certain language then you should try to get the students to use that language as much as possible. I don't see how there can be any other position really" (P6). She also emphasized that students already have a lot of English from 6 years of English instruction at junior and senior high school, albeit usually highly exam-oriented, and that the university teacher's role is to make them active communicators in the L2 and maximize the opportunities to use what they have: "It's there. It's locked away. It just needs the right opportunity, the right conditions to bring it out" (P6).

One teacher emphasized the need to make an L2-only policy for students' language use absolutely clear from the beginning ("First day I announce this is an English-only class," P10) and to stress that English is a language to be used for the process of "real" communication and not simply as a product for passing exams. In trying to establish an L2-only classroom culture, she extends her policy to all the time that she is actually present in the room. Rather than this leading to silence among students when the class is formally over, they be- 
come comfortable with their peers in using English for a "real" communicative purpose: "As I leave I hear them saying to each other Are you going for coffee? or Let's get something to eat." On commenting on teachers who allow students to use Japanese for the process of naturalistic classroom exchanges, she takes the opinion that "It's telling them that English is not for real communication."

To effectively manage a strong English-only policy regarding students' use of L2, teachers employed a range of techniques and strategies of instruction and classroom management. This involved the teaching of appropriate formulaic phrases and communication strategies that students could use, such as language for requesting and giving clarification, and for conversation expansion. It also involved giving an explicit rationale for an L2-only approach, outlining how L2 maintenance contributed to grading, and the orientation of students in terms of attitude and expectations. Class management involved such strategies as constant pairing up of different students, changing topic often, setting task time limits, and cutting short tasks that proved too challenging for maintaining L2 use. Maintenance of a strong L2only policy among students also required constant monitoring and verbal reminders or "cajoling and coaxing" (P9), as one participant put it.

Clearly, those who adopt a more learner-centered orientation with high levels of student/student interaction will require considerable management skills and monitoring if they wish to impose and maintain English-only communication among students. Other teachers may restrict interaction to a highly teacher-fronted mode of initiation/response/feedback as a way of controlling and getting students to talk only in the L2, even though the quantity and quality of the communication may be very limited with large classes.

\section{Rationale for Students' Use of $L 1$}

There were a few teachers who, while adopting a strong English-only policy for their own language use, were more flexible regarding their students. Examples of when they actively encouraged students' use of Japanese were for the purpose of clarifying among themselves a teacher's instructions and for peer assessment tasks. One teacher, though strongly committed to using only English herself in class, stated "I am much more flexible and permissive about students using L1 among themselves" (P4). She also observed that her attitude toward enforcing L2-only use had changed considerably over the years: "I have softened. At the beginning I was much more of the opinion that it should be English. Speak only English in class. When it didn't work I tried to force it, and that made me uncomfortable." 
Her views in particular raise the issue of the nature of classroom content and goals as contributing factors to language use policy. If the type of content is simple personalized day-to-day topics (such as family, food, shopping), L2-only use may not be too demanding. However, if the class content is more sophisticated, requiring critical thinking skills and greater language complexity, then enforcing L2-only use will for many students be counterproductive. Indeed, making this shift from students talking about simplistic, and perhaps, trivial topics and experiences to discussing opinions, values, and ideas related to more challenging issues and content may well be a major influence on language use policy. Not surprisingly, this teacher's view regarding students' use of L1 reflected a high degree of flexibility and goalorientation. Referring to a content course that she taught, she emphasized that “I wouldn't impose English only on them ... I would prefer them to speak Japanese" (P4). She supported her approach by emphasizing the importance of plenty of rich L2 input, having respect for students' self-regulation, and the influence of Vygotskian sociocultural theory.

Another teacher implicitly referred to principles of critical pedagogy in supporting students' use of the L1. While a few teachers were unashamedly authoritarian in their use of language (e.g., "I say what I want," P6), and others expressed awareness of their position of power (e.g., "I'm not an English imperialist," P3), this teacher appeared to be particularly sensitive when interviewed to using any language that reflected power and control over students or the exercising of teacher authority (e.g., "I nearly used the word 'control' there, didn't I?" P9). His guiding principles were stated as non-imposition, communication, and the freedom to speak: "I am not going to stop anyone from communicating in class." Students' freedom to communicate in the L1 extended to group project work and preparation of presentations ("I don't really mind how they get there"). He described L2-only policy as "another imposition of I am the boss, I am the one with your grade" and commented on such extreme measures as fining students for using the L1 as being restrictive, controlling, and a reflection of how "the power situation is made very clear, who is in charge and who isn't."

While the above teacher's approach appears to have a clear critical perspective in terms of valuing learners' freedoms and rights to use the L1, it is still essentially a top-down policy determined by the teacher. This leads on appropriately to another critical consideration: that of negotiating classroom language policy. 


\section{Negotiation of Policy}

One possibility for getting students' views on L1 use is at the beginning of a course to give open questionnaires which may then form the basis for discussion and negotiation of policy. Auerbach (2000) has suggested using awareness-raising model dialogues which can present both sides of the argument and encourage students to discuss their own views on the issue. I was interested to see whether the teachers in this study used negotiation not only as a democratic principle reflecting a critical perspective, but also as a strategy for getting student commitment to L2 communication.

Surprisingly, not one of the 10 interviewees had really used a process of negotiation of language use policy or of specific occasions when L1 and L2 use would be appropriate. In fact, in response to the relevant interview question about negotiation (see Appendix), most teachers offered only very limited comments (e.g., "no, not really" or "no, not explicitly") followed by no further reflection on the issue. However, four of the teachers did offer other views. One teacher recognized that while "negotiation shows respect, gives them investment," his policy was "nonnegotiable" (P8), and he suggested that it would not be a particularly useful process. Another expressed a similar reserve about the efficacy of negotiating policy. In his case, while students attending the university's coordinated English program are asked to discuss why a strong English-only policy is important, the policy is very much a "set agenda," and he considered that once an English-only policy for teachers and students had been established and rationalized as a feature of the program, negotiation of one of its underlying tenets would only prove counterproductive: "What if they come up with, 'Well, we don't have to use English.? What are you going to do?" (P2).

While negotiation of policy was something they had not tried, two teachers seemed to be more open to considering the possibility. One stated after some hesitation and reflection that he liked the idea and that "I should listen to their opinions" (P1). Another observed "I have been a bit undemocratic in that respect" but suggested that students would probably say that they wanted to speak as much Japanese as possible. She concluded, however, on a more conciliatory note, that "Maybe they would surprise me; maybe it's something I'll try" (P6).

Despite not negotiating their L1/L2 policy, the majority of teachers expressed a strong belief in their approach and that for many of them negotiation could well undermine a policy that they are used to, feel is appropriate, and feel comfortable with. Indeed, in response to the interview question about consistency of policy (see Appendix), most said that they had not real- 
ly changed it much over the years, and that it was probably more dependent on their own personality and experiences, as reflected by such comments as: "I'm not like that" (P5), "I'm not very good at being hard line" (P4), and "It's not my style" (P8). As one teacher concluded on this issue, "I've arrived at this point of my principles through intuition and pragmatic reasons" (P3).

\section{Institutional Policy}

Most teachers at universities in Japan are not generally constrained by institutional requirements in determining their policy regarding classroom language use. This indeed was the case with nearly all the teachers interviewed. Some observed that in all their time in Japan they had never seen or been given any guidelines regarding this issue ("It is pretty much up to the teacher ... I have never seen anything explicit," P3). There were two exceptions to this that reflect opposing positions. In the case of one university a change in policy was giving explicit support for teachers to actively use Japanese when formerly it had emphasized staying in English. However, this was only done through a relatively loose directive in a teachers' handbook. This may reflect an increasing trend in the future as the lowering of English standards results in some departments advising English teachers that they can or should use Japanese if students are of such a low level that they cannot understand even the most basic speech in English.

Though most teachers appear to be at liberty to determine their own policies, in a few exceptional cases there may be an institutionally determined policy which demands that teachers and students follow a particular approach to the language used in the classroom, regardless of individual personalities or preferences. Indeed, one of the teachers interviewed was part of a program with a strong institutionalized English-only policy. In-house teacher workshops emphasized the importance of establishing a culture among teachers and students through training and sharing ways to assist in managing classes in a way that values and raises expectations of an L2-only policy. Student orientation included rationalizing the approach to students, such as explaining why an English-only class is beneficial and why Japanese is not to be used.

This example of a strong orientation toward L2-only teacher and student language use has been highly successful in producing and maintaining high levels of motivation and achievement at a university where students are all language majors and have therefore made a very conscious and deliberate choice to be studying English. It is an institution where all the necessary facilities and support are provided to assist their study, including a state-ofthe-art self-access centre. In addition, while teachers are expected to commit 
to the institution's classroom language policy, they are also encouraged to be involved in research and teacher development. This situation, of course, is in sharp contrast to the situation of most of the teachers in this study, who are taking decisions independently and unilaterally about their teaching practices, without constraints, or indeed support, from a coordinated program.

\section{Conclusion}

In reviewing the literature for this study, particularly relating to Japan and other EFL contexts, I found that it was mainly limited to reviewing arguments for and against L1 use and to student questionnaires about preferences. There also seemed to be a general view that English only, as a principle of communicative methodologies, has been the dominant approach in FL settings, though this seems to be based on presumptions about pedagogic traditions rather than on findings from rigorous research. I found no evidence of qualitative, interview-based research concerning teachers' actual policies on this issue at Japanese universities, and so there was a clear rationale for undertaking such a study.

The results showed that 9 of the 10 interviewees tended to follow an Englishonly approach concerning their own language use. There was a greater degree of flexibility in terms of student language use, with only three teachers claiming a near zero tolerance of L1 use among students. Those teachers who used Japanese occasionally in class clarified the purpose as primarily humor, creating a relaxed atmosphere, giving instructions and task directions. However, none appeared to have established a particularly systematic approach with explicit guidelines regarding the occasions of their own or students' L1 use.

One teacher's L1 use was guided by taking a critical approach to language pedagogy, and another was committed to a strong L2-only institutional policy. Most teachers, however, emphasized the need for a flexible and pragmatic approach, especially concerning student L1 use, depending on student level, motivation, and nature of class content. Above all, teachers underlined the need to feel comfortable with the approaches that they take, with their L1/L2 policies tending to be more the result of personal beliefs and experiences, practical considerations, personality and intuition, as opposed to adherence to any ingrained teaching dogma, training, ideology, or principles of language learning theory.

This study has explored the classroom language policies and the principles and practices of L1/L2 use by only 10 EFL practitioners, and it is limited to the context of Japanese universities. It has provided just one method of undertaking qualitative research in this area. Future qualitative research 
might employ longitudinal individual case studies and classroom ethnography over the period of an academic year, involving the triangulation of various data sources, such as classroom observation, teacher and student journals, as well as interviews. Specific areas of research might focus on how L1 use can be systematized, how a strong L2-only policy and L2 classroom culture is established and maintained, or how classroom language policy affects and is affected by teachers' personalities and identities.

\section{Acknowledgement}

I would like to give thanks to the two anonymous reviewers whose advice helped me revise this article for publication, and also to Ayako Suzuki for providing the Japanese translation of the abstract.

\section{References}

Auerbach, E. R. (1993). Reexamining English only in the ESL classroom. TESOL Quarterly, 27, 9-32.

Auerbach, E. R. (1994). The author responds... TESOL Quarterly, 28, 157-161.

Auerbach, E. R. (2000). Creating participatory learning communities: Paradoxes and possibilities. In J. K. Hall \& W. G. Eggington (Eds.), The sociopolitics of English language teaching (pp. 143-164). Clevedon: Multilingual Matters.

Barker, D. (2003). Why English teachers in Japan need to learn Japanese. The Language Teacher, 27(2), 7, 9-11.

Bawcom, L. (2002). Over-using L1 in the classroom? Modern English Teacher, 11 (1). Retrieved September 24, 2007, from http:// www.eltforum.com/articles/ free/129.pdf

Burden, P. (2000). The use of the students' mother tongue in monolingual English "Conversation" classes at Japanese universities. The Language Teacher, 24(6), 5-11.

Clanfield, L. \& Foord, D. (2003). Using L1 in the classroom. Humanising Language Teaching, 5(1). Retrieved September 20, 2007, from http://www.hltmag.co.uk/ jan03/mart2.htm.

Cohen, L., Manion, L. \& Morrison, K. (2000). Research methods in education. London: Routledge/Falmer.

Cole, S. (1998). The use of L1 in communicative English classrooms. The Language Teacher, 22(12), 11-13.

Cook, V. (2001). Using the first language in the classroom. Canadian Modern Language Review, 57, 402-423. 
Corson, D. (1999). English only and social justice. TESOL Journal, 8(3), 18-22.

Cox, M.I. P., \& Assis-Peterson, A. A de. (1999). Critical pedagogy in ELT: Images of Brazilian teachers of English. TESOL Quarterly, 33, 433-452.

Critchley, M. P. (1999). Bilingual support in English classes in Japan: A survey of student opinions of L1 use by foreign teachers. The Language Teacher, 23(9), 10-13, 3.

Cullen, B. \& Morris, J. (2001). A case for using Japanese in college English classes. On CUE, 9(3), 4-9.

Freire, P. (1972a). Pedagogy of the oppressed. Harmondsworth: Penguin.

Freire, P. (1972b). Cultural action for freedom. Harmondsworth: Penguin.

Giroux, H. A. (1988). Schooling and the struggle for public life: Critical pedagogy in the modern age. Minneapolis: University of Minnesota Press.

Glick, C. (2002). Considerations for securing an English teaching position at a Japanese university (Part 2). The Language Teacher, 26(9), 19-22.

Habermas, J. (1972). Knowledge and human interests. London: Heinemann.

Lantolf, J. (Ed.) (2000). Sociocultural theory and second language learning. Oxford: Oxford University Press.

McAulay, A. (2002). The paradox of enforced monolingualism for incipient bilinguals. On CUE, 10(1), 19-20.

Mills, J. (2001). Self-construction through conversation and narrative in interviews. Educational Review, 53, 285-301.

Pennycook, A. (1990). Towards a critical applied linguistics for the 1990s. Issues in Applied Linguistics, 1, 8-28.

Pennycook. A. (1994). The cultural politics of English as an international language. London: Longman.

Phillipson, R. (1992). Linguistic imperialism. Oxford: Oxford University Press.

Polio, C. (1994). Comments on Elsa Auerbach's “Reexamining English only in the ESL classroom." TESOL Quarterly, 28, 154-157.

Prodromou, L. (2002). The role of the mother tongue in the classroom. IATEFL Issues (April-May), 6-8.

Ryan, S. (2002). Maximising L2 communication: The case for caution in the use of L1 in the classroom. On CUE, 10(1), 20-21.

Skutnabb-Kangas, T. (1999). Linguistic human rights - Are you naïve, or what? TESOL Journal, 8(3), 6-12. 
Weschler, R. (1997). Uses of Japanese (L1) in the English classroom: Introducing the functional-translation method. The Internet TESL Journal, 3(11). Retrieved September 20, 2007, from http://iteslj.org/Articles/Weschler-UsingL1.html

Yamamoto-Wilson, J. R. (1997). Can a knowledge of Japanese help our EFL teaching?

The Language Teacher, 21(1), 6-9.

\section{Appendix}

\section{Interview Questions}

1. To what extent do you feel you try to follow an English-only policy in the classroom?

2. Do you make your language policy explicit to students from the first few classes?

3. Do you ever consult or negotiate with students about classroom language policy?

4. Can you give examples of when you use the L1 yourself in class?

5. How would you describe your Japanese proficiency?

6. To what extent do you demand and monitor L2 use in pair and group work?

7. Do you include staying in English as part of grading, and if so do students know this?

8. What are some of the techniques you use for keeping your students talking in English?

9. How do you feel when students don't use English and how do you respond?

10. Do you feel you are generally successful at carrying out your policy?

11. What are some of the constraints you find yourself under in carrying out your policy?

12. Is there a general policy at any of the universities where you teach regarding how and when English should be used in the classroom? And if so, do you take that policy into account?

13. Do you feel your policy and attitudes have been consistent over the years or have they changed in some way?

14. Do you think your policy is primarily the result of theory, principle, intuition, experience, pragmatism, or something else? 